\title{
Inflammatory mediators related to arthrogenic temporomandibular dysfunctions
}

\author{
Mediadores inflamatórios relacionados às disfunções temporomandibulares artrogênicas
}

Rodrigo Lorenzi Poluha1, Eduardo Grossmann²

DOI 10.5935/2595-0118.20180013

\section{ABSTRACT}

BACKGROUND AND OBJECTIVES: Inflammatory disorders of the temporomandibular joint present a high prevalence in the population. The knowledge about inflammatory mediators, such as histamine, serotonin, kinins, eicosanoids, platelet-activating factor, nitric oxide, tumor necrosis factor and interleukins, may contribute to a better understanding of these disorders. The objective of this study was to review the literature on the major inflammatory mediators involved in temporomandibular arthralgia.

CONTENTS: A search was made in the LILACS, Pubmed/ Medline, Scielo and Science direct databases, crossing the following descriptors in the English and Portuguese language: inflammation, temporomandibular joint, inflammatory mediators, inflammation, temporomandibular joint and inflammatory mediators. Articles of literature review, systematic review, meta-analysis and randomized clinical trials, as well as books with compatible themes, published between September 1990 and June 2017 were included. Clinical reports, open label studies, animal model studies, were excluded.

CONCLUSION: The knowledge of the inflammatory process, with the different mediators and mechanisms, can contribute to a better understanding, allowing the selection of the best therapy to be used clinically in cases of arthrogenic temporomandibular joint disorders.

Keywords: Inflammation, Inflammatory mediators, Temporomandibular joint disorder.

\footnotetext{
1. Universidade Estadual de Maringá, Maringá, PR, Brasil.

2. Universidade Federal do Rio Grande do Sul, Porto Alegre, RS, Brasil.

Submitted in September 01, 2017.

Accepted for publication in January 10, 2018

Conflict of interests: none - Sponsoring sources: none.

Correspondence to:

Rua Coronel Corte Real, 513 - Petrópolis

90630-080 Porto Alegre, RS.

E-mail- edugdor@gmail.com

(C) Sociedade Brasileira para o Estudo da Dor
}

\section{RESUMO}

JUSTIFICATIVA E OBJETIVOS: As desordens inflamatórias da articulação temporomandibular apresentam alta prevalência na populaçáo. O conhecimento sobre os mediadores inflamatórios, tais como histamina, serotonina, cininas, eicosanoides, fator de ativação plaquetária, óxido nítrico, fator de necrose tumoral e interleucinas, pode contribuir para melhor entendimento dessas desordens. O presente trabalho objetivou revisar a literatura a respeito dos principais mediadores inflamatórios envolvidos nas artralgias temporomandibulares.

CONTEÚDO: Foi realizada uma busca nas bases de dados LILACS, Pubmed/Medline, Scielo e Science direct, cruzandose os seguintes descritores em língua inglesa e portuguesa: inflammation, temporomandibular joint, inflammatory mediators, inflamação, articulação temporomandibular e mediadores inflamatórios. Foram incluídos artigos de revisão de literatura, revisão sistemática, meta-análise e estudos clínicos randomizados, bem como livros com temática compatível, publicados no período de setembro de 1990 a junho de 2017. Foram excluídos casos clínicos, estudos abertos «open-label» e estudos em modelos animais. CONCLUSÁO: O conhecimento do processo inflamatório, com os diferentes mediadores e mecanismos, pode contribuir para um melhor entendimento do mesmo, possibilitando a seleçáo da melhor terapêutica para ser empregada clinicamente nos casos de artralgias temporomandibulares.

Descritores: Inflamação, Mediadores inflamatórios, Transtornos da articulação temporomandibular.

\section{INTRODUCTION}

Temporomandibular dysfunction (TMD) is a set of functional and pathological changes that affect the masticatory muscles, associated structures, and the temporomandibular joint $(\mathrm{TMJ})^{1}$. The TMJ is considered a ginglymoarthrodial joint that allows rotational and translational motion. These movements are essential in mastication, speech, and swallowing ${ }^{2,3}$.

TMJ inflammatory disorders have a $34.2 \%$ prevalence in the population ${ }^{4}$. It can occur due to trauma or an intrinsic and/or extrinsic joint overload that exceeds the adaptive capacity of the joint tissues, generating an inflammation as a consequence, ${ }^{5,6}$. Inflammation is a set of homeostatic phenomena in the vascularized tissues to remove harmful agents and to restore their normal functions. These phenomena are coordinated by the action of inflammation mediators (IM) $)^{7-9}$. Histamine, serotonin, kinins, eicosanoids, platelet activating factor, nitric oxide, tumor ne- 
crosis factor, and interleukins are among the main IM of TMJ disorders ${ }^{10,11}$.

Therefore, understanding these IM can contribute to a better understanding the disorders, as well as to select the proper therapy, as the anti-inflammatory pharmacology, intra-articular injections, arthrocentesis, and arthroscopy ${ }^{12,13}$, in order to optimize the clinical outcome.

The objective of the present study was to review the literature about the main IM involved in temporomandibular arthralgia.

\section{CONTENTS}

\section{Literature search strategies}

A search was conducted in the LILACS, Pubmed/Medline, Scielo, and Science direct databases, crossing the following keywords in English and in Portuguese: "inflammation", "inflammation mediators", "temporomandibular joint" "temporomandibular joint disorders," "inflamação", "mediadores da inflamaçáo", "articulação temporomandibular" and "transtornos da articulação temporomandibular". We included review articles, systematic review, meta-analysis and randomized clinical studies, as well as books on compatible themes published from September 1990 to June 2017. Reports of clinical cases, "open-label" studies, studies with animal models were excluded. We found a total of 95 study materials (articles and books). Of these, after reading the summary, 50 articles and 6 books met the inclusion criteria and provided the basis for the writing of the present study.

\section{Inflammatory joint disorders of the temporomandibular joint}

It is a series of alterations in which some tissues that compose the joint structure suffer an inflammatory process, being classified according to the structures affected in synovitis, capsulitis, retrodiscitis, ligamentitis, and arthritis ${ }^{14,15}$. Usually, it is difficult to make a differential diagnosis of these arthrogenic alterations due to their clinical similarities ${ }^{16}$.

The inflammation of the synovial membrane that lines the TMJ (synovitis) results in changes in the composition and amount of the synovial fluid ${ }^{17}$. Clinically, it is characterized by a persistent intracapsular pain that is intensified with the jaw movement ${ }^{14}$. When intense, necrosis and fibrin deposition in the joint surface may occur which reduces the joint space and eventually leading to a TMJ fibrous ankylosis ${ }^{18}$.

The inflammation of the TMJ capsular ligament (capsulitis), is clinically manifested by pain on palpation of the lateral head pole of the jaw when in static joint position and in motion. The most frequent etiologic factor is the macro trauma when the capsular ligament is abruptly stretched ${ }^{14,15}$. During the healing process, the joint capsule can adhere to adjacent structures (adhesive capsulitis) or heal with loss of length (capsular fibrosis ${ }^{18}$.

The inflammation of the TMJ retrodiscal tissue (retrodiscitis) is characterized by a pulsating pain ${ }^{15}$, which can lead to acute malocclusion in the contralateral anterior jaw due to local edema. Macro and microtrauma that force the mandibular condyle towards the innervated and vascularized retrodiscal tissues may cause a retrodiscitis ${ }^{14}$. The intensity of the trauma and the progression of the inflammatory process can cause the perforation of retrodiscal tissues and put the mandibular condyle in direct contact with the mandibular fossa ${ }^{18}$.

The inflammation of the disc ligaments (ligamentitis) is a result of macro or microtrauma, bruxism and/or functional acts of broad magnitude in an attempt to move the disc of the mandibular condyle. Usually, it results in intermittent pain, increasing by maximum intercuspation and reducing by the interposition of a dental spatula. It can be associated with pain, protective muscle co-contraction, and limitation of jaw movements ${ }^{14}$.

The inflammation of the joint surfaces (arthritis) is a group of disorders in which we observe changes in the morphology of the bone tissue. Several types of arthritis can impact the TMJ (osteoarthritis, osteoarthrosis, and polyarthritis). The level of pain and the clinical and image findings vary tremendously in the different types ${ }^{14}$.

\section{INFLAMMATION MEDIATORS}

Inflammation mediators are substances released in an injured tissue area or by properly activated cells that coordinate the process of the inflammatory response ${ }^{19}$ (Table 1).

Table 1. Summary of the key inflammation mediators found in arthrogenic temporomandibular dysfunctions

\begin{tabular}{|c|c|c|}
\hline Mediators & Sources & Actions \\
\hline Histamine & $\begin{array}{l}\text { Mast cells, basophils, platelets, epidermal cells } \\
\text { and neurons of the central nervous system. }\end{array}$ & $\begin{array}{l}\text { Vasodilation; vascular permeability increase; endothelial activation and } \\
\text { stimulation of the serotonin release. }\end{array}$ \\
\hline Serotonin $(5-\mathrm{HT})$ & $\begin{array}{l}\text { Serotonergic neurons of the central nervous } \\
\text { system and enterochromaffin cells. Platelets } \\
\text { (that capture 5-TH in the circulation). }\end{array}$ & Vasodilation; increased vascular permeability and nociception. \\
\hline Kinins (bradykinin) & $\begin{array}{l}\text { Plasma substrate, by the metabolization of } \\
\text { kininogen by kallikrein. }\end{array}$ & $\begin{array}{l}\text { Vasodilation; increased vascular permeability; promotion of the IL-1 and } \\
\text { TNF synthesis and activation of phospholipases } \mathrm{A}_{2} \text { and C. }\end{array}$ \\
\hline Prostacyclin $\left(\mathrm{PGI}_{2}\right)$ & Mast cells from membrane phospholipids. & Increment the effect of histamine and kinins. \\
\hline $\begin{array}{l}\text { Prostaglandins } \\
\left(\mathrm{PGE}_{2}, \mathrm{PGF}_{2}\right)\end{array}$ & Mast cells from membrane phospholipids. & Increment the effect of histamine and kinins; nerve endings hyperalgesia. \\
\hline Thromboxane $\left(\mathrm{TxA}_{2}\right)$ & Mast cells from membrane phospholipids. & Intravascular coagulant; keep intravascular normality. \\
\hline Leukotrienes $\left(\mathrm{LTB}_{4}\right)$ & Leucocytes. & Chemotaxis, polymorphonuclear leukocytes aggregation, and degranulation. \\
\hline
\end{tabular}


Table 1. Summary of the key inflammation mediators found in arthrogenic temporomandibular dysfunctions - continuation

\begin{tabular}{|c|c|c|}
\hline Mediators & Sources & Actions \\
\hline $\begin{array}{l}\text { Platelet activation } \\
\text { factor (PAF) }\end{array}$ & Leukocytes, mast cells, and platelets. & $\begin{array}{l}\text { Vasodilation; an increase of capillary permeability, chemotaxis, aggrega- } \\
\text { tion, and degranulation of polymorphonuclear leukocytes. }\end{array}$ \\
\hline Nitric oxide & Macrophages, endothelial cells. & Vasodilation; reduction of platelet aggregation. \\
\hline $\begin{array}{l}\text { Tumor necrosis fac- } \\
\text { tor }(\text { TNF- } \alpha)\end{array}$ & $\begin{array}{l}\text { Monocytes, macrophages, and T-lym- } \\
\text { phocytes. }\end{array}$ & $\begin{array}{l}\text { Coagulation activation; stimulation of the expression of adhesion mo- } \\
\text { lecules, PGE }{ }_{2} \text {, PAF, glucocorticoids, eicosanoids, besides influencing } \\
\text { cellular apoptosis. }\end{array}$ \\
\hline Interleukin-1 (IL-1) & $\begin{array}{l}\text { Macrophages, monocytes, fibroblasts, den- } \\
\text { dritic cells, B lymphocytes, NK cells and epi- } \\
\text { thelial cells. }\end{array}$ & $\begin{array}{l}\text { An important marker of the inflammatory response associated with acu- } \\
\text { te Infection. }\end{array}$ \\
\hline Interleukin-1 (IL-6) & $\begin{array}{l}\text { Monocytes, macrophages, fibroblasts, en- } \\
\text { dothelial cells. }\end{array}$ & $\begin{array}{l}\text { Regulation of immune reactions, inflammation, hematopoiesis, and car- } \\
\text { cinogenesis; maturation and activation of several inflammatory cells. }\end{array}$ \\
\hline
\end{tabular}

\section{Histamine}

Histamine is a vasoactive amine formed by the histidine decarboxylation by the l-histidine enzyme decarboxylase, found in the mast cells, basophils, platelets, cells of the human epidermis, gastric mucosa, and neurons of the central nervous system $(\mathrm{CNS})^{20}$. The tissue aggression leads to the degranulation of the mast cells ${ }^{8}$, usually found in the retrodiscal zone and contributes to the TMJ inflammation mainly through the release of histamine ${ }^{21}$. In the inflammatory process, histamine promotes the vasodilation, increasing vascular permeability, and endothelial activation, and its effects are mediated by the interaction with four receptors $(\mathrm{H} 1, \mathrm{H} 2, \mathrm{H} 3$, and $\mathrm{H} 4)$. $\mathrm{H} 1$ receptors are essentially found in blood vessels, and they promote vasodilation, bronchoconstriction, and modulation of the circadian rhythm. $\mathrm{H} 2$ receptors are in the intestine and induce the secretion of gastric acid. The H3 predominates in the CNS acting as neurotransmitters. $\mathrm{H} 4$ is widely expressed in the bone marrow and leukocytes and mediates the mast cells chemotaxis ${ }^{7}$. Following one to two hours after the aggression, the receptors of the endothelial cells become hyposensitive to the histamine action, and the exudative phenomena continue by other mediators ${ }^{8}$. Histamine inactivation occurs by for methylation in the liver, or oxidation in the kidneys and intestines through histaminase ${ }^{7}$. Histamine concentration tends to be higher in patients with osteoarthritis than with other TMJ disorders, having, in addition, a positive correlation between the pain and the concentration of this amine ${ }^{22}$. Histamine induces the nociception through an indirect mechanism stimulating the 5-hydroxytryptamine release (5-HT, serotonin) ${ }^{23}$.

\section{Serotonin (5-HT)}

5-HT is an amine found in the animal and vegetal kingdoms. It is synthesized in the serotonergic neurons of the CNS and in the enterochromaffin cells (Kulchitsky cells) of the gastrointestinal tract of the animals. In the human body, 5-HT is synthesized from the tryptophan amino acid by short metabolic pathway, that involves two enzymes: tryptophan hydroxylase and aromatic L-amino acid descarboxylase ${ }^{7}$. Although being better known by its action as a neurotransmitter in the CNS, 5-HT contributes to vasodilation and the increase of vascular permeability, in inflammation, being released by platelets (that take 5-TH from of the circulation, storing in secretory granules by active transport) at the moment of its aggregation ${ }^{24}$. The levels of 5-HT in the syno- vial fluid of the temporomandibular arthralgias, in patients with arthritis, show that it is significantly increased and related to pain during the movement of the joint and the reduction of the mandibular mobility ${ }^{25}$. 5-HT also induces nociception in the TMJ region by the activation of $\beta 1$ and $\beta 2$ adrenoreceptors located in this joint, and also the local release of adrenergic amines and prostaglandins. Therefore, high levels of 5-HT in the synovial fluid of patients with TMJ inflammatory pain can contribute to the maintenance of the painful picture ${ }^{26}$.

\section{Kinins}

Kinins (bradykinin, lysyl-bradykinin, and methionyl-lysyl-bradykinin) keep the exudative phenomena after the hypersensitization to histamine, with effectiveness 10 times higher ${ }^{8}$. Kinins interact with specific receptors $\left(B_{1}\right.$ and $\left.B_{2}\right)$, present in inflammatory cells, like macrophages, promoting the synthesis of interleukin-1 and the tumor necrosis factor (TNF) (when coupled to $B_{1}$ ) receptors, activating $A_{2}$ and $C$ phospholipases (when coupled to $\mathrm{B}_{2}$ receptors) ${ }^{24}$. Bradykinin has been implied in the pathogenesis of the TMJ inflammatory conditions due to its pro-inflammatory properties ${ }^{27}$. The increase of bradykinin levels in the synovial fluid of patients with temporomandibular dysfunction (TMD) can indicate the lower effectiveness of using arthrocentesis in this joint ${ }^{28}$ since there is a positive correlation between the concentration of bradykinin and the synovitis degree ${ }^{29}$.

\section{Eicosanoids}

Eicosanoids are composites with great potency and a broad spectrum of biological activity, being originated by the oxygenation of long-chain polyunsaturated fatty acids ${ }^{19}$. The arachidonic acid (AA), present in cell membranes, is the most abundant and important eicosanoid precursor ${ }^{20}$. AA is present in the membranes of the body cells. It is an essential fatty acid, of the Omega-6 family, formed by a 20 -carbon chain with four double bonds (allowing several areas of the molecule to be oxidized) ${ }^{7}$. The cell stress resulting from the injury generates, as a consequence, an increase of calcium permeability with higher inflow to the interior of the cell, activating the action of the acyl-hydrolases enzymes (phospholipase $\mathrm{A}_{2}$ and $\mathrm{C}$ ) that breaks up the phospholipids and promotes the generation of AA molecules available in the cytosol ${ }^{8}$. AA is oxidized, mainly, by five enzymatic pathways (two cyclooxygenases and three lipoxygenases) producing eico- 
sanoids (prostaglandins, thromboxanes, leukotrienes), that play a fundamental role in the inflammatory process ${ }^{20}$.

\section{Cyclooxygenase products}

Cyclooxygenase (COX), enzymes present in the cytosol and bond to the endoplasmic reticulum of the cells, generate the synthesis of prostaglandins ( $\mathrm{PGE}_{2}, \mathrm{PGF}_{2}$ ), prostacyclins $\left(\mathrm{PGI}_{2}\right)$ and thromboxanes $\left(\mathrm{TxA}_{2}\right)^{20}$. Prostaglandins and prostacyclins act as modulators of the exudative phenomena in late periods (after some hours of the onset of the inflammatory process) incrementing the histamine and kinins effect on the specific receptors, by increasing its sensitivit $y^{24}$. Moreover, prostaglandins promote nerve endings hyperalgesia making them more sensitive to the action of pain mediators (histamine, serotonin, and kinins) which makes the local pain, induced by mechanical and chemical agents, stronger ${ }^{8}$. $\mathrm{PGE}_{2}$ is present in high concentrations in the synovial fluid of TMJ involved in an inflammatory process, playing an important role in the development and maintenance of the inflammation ${ }^{30}$, such as the allodynia involved in these processes through the regulation of the 1.7 voltagedependent sodium channels that have a modulating function in this type of pain $^{31}$. The TxA $\mathrm{A}_{2}$ is an important intravascular coagulant, being physiologically inhibited by $\mathrm{PGI}_{2}$ (vasodilator). This constant opposition maintains the intravascular normality ${ }^{8}$.

\section{Lipoxygenase products}

In the leukocytes, part of the AA molecules is submitted to the action of lipoxygenases (5-, 12- and 15-LOX), resulting in the formation of leukotrienes (LT) ${ }^{7}$. Leukotrienes have a chemotactic function, aggregation, and degranulation of polymorphonuclears, as well as the stimulation of leukocytes adherence to the endothelial wall during the formation of the inflammatory infiltrate ${ }^{8}$. High concentrations of leukotrienes $\left(\mathrm{LTB}_{4}\right)$ are found in the synovial fluid of inflamed TMJ ${ }^{32}$, having a positive correlation between the degree of synovitis and the level of $\mathrm{LTB}_{4}^{29}$.

\section{Platelet activating factor}

As a response to specific stimuli (immune, tissue injuries), during the phosphorylation of phospholipids in phospholipase, there is also the formation of the platelet activating factor (PAF) that is released by leukocytes, mast cells, and platelets ${ }^{8}$. PAF induces the expression of adhesion molecule that recruits the inflammatory cells to the endothelium, in addition to contributing to the inflammation exudative phenomena when produced by mast cells and leukocytes ${ }^{24}$. High concentrations of PAF are found in inflammatory processes involving the TMJ ${ }^{32}$.

\section{Nitric oxide}

Nitric oxide (NO) is a free radical that is formed from the conversion of L-arginine and L-citrulline by nitric oxide enzymes synthetases, in endothelial cells in the CNS, the cardiac muscle, and macrophages ${ }^{24}$. NO promotes muscle relaxation of blood vessels leading to vasodilation (a process that culminates in the formation of hyperemia and hyperthermia in inflammatory processes), besides reducing platelet aggregation ${ }^{8}$. In the TMJ, NO is involved in painful conditions ${ }^{33}$ as well as in the pathogenesis and the progression of internal disorders ${ }^{34}$.

\section{Pro-inflammatory cytokines}

The migration of cells to the region where the inflammation is occurring is also strongly influenced by the cytokines action ${ }^{35}$. These are peptides or polypeptides produced by the inflammatory or tissue cells, in conditions of normality, but also, especially, in cell mechanic, biochemical and/or functional cell stress as it is characterized in an area with an inflammatory process ${ }^{8}$. Besides stimulating the leukocyte cell adhesion to the vascular endothelium and inducing the synthesis and release of prostaglandins, the increase in the concentration of pro-inflammatory cytokines has been associated to the reabsorption of bone tissue in the TMJ ${ }^{36}$. Among the cytokines in the TMJ inflammation are the tumor necrosis factor (TNF- $\alpha$ ) and the interleukins (especially IL-1 and IL-6) ${ }^{37}$.

\section{Tumor necrosis factor}

TNF- $\alpha$ is a pro-inflammatory cytokine mainly produced by monocytes, macrophages, and T-linphocytes ${ }^{35}$. After traumas, surgical procedures or during infections, the TNF- $\alpha$ is one of the earliest and potent mediators of the inflammatory response. Its plasma half-life is only 20 minutes, enough to cause metabolic and hemodynamic important changes and to activate other cytokines $^{38}$. TNF- $\alpha$ acts activating coagulation, stimulating the expression or release of adhesion molecules, $\mathrm{PGE}_{2}$, PAF, glucocorticoids, eicosanoids and influencing cell apoptosis ${ }^{39}$. This cytokine plays a key role in the development of $\mathrm{TMD}^{40}$. Its increased expression promotes the beginning and progression of multiple inflammatory diseases, including the ones that involve the TMJ ${ }^{41}$. This fact is confirmed by results in which high TNF- $\alpha$ levels in the TMJ are positively correlated with acute and chronic joint inflammation, destruction of the connective tissue and pain in this joint ${ }^{42,43}$.

\section{Interleukin-1 (IL-1)}

IL-1 is intensely produced by macrophages, monocytes, fibroblasts and dendritic cells, but it is also expressed by B lymphocytes, NK cells, and epithelial cells, and it is one of the most important markers of induction of the inflammatory response associated with acute infection ${ }^{44}$. The IL-1 system includes, at least, 21 different molecules represented by the IL-1 receptors, co-receptors, antagonists, and endogenous ligands. There are three types of ligands: IL- $1 \alpha$ and IL-1 $\beta$ (both have an almost indistinguishable pro-inflammatory effect), and the IL-1 receptor antagonist (IL-1RA) that inhibits the pro-inflammatory functions acting as a competitive inhibitor of the receptor. There are also two different IL-1 receptors: the type 1 and type 2 . The type 1 IL-1 receptor is responsible for the induction of intracellular signal transductions after binding with IL-1. The type 2 IL-1 receptor acts binding to IL-1 without producing any effect, thus reducing its general availability to bind and to initiate an inflammatory response $\mathrm{e}^{45}$. The intricate balance of molecules and receptors of the IL-1 family has a deep effect on the TMJ homeostasis. Many studies indicated that higher levels of IL- $1 \alpha$ and IL-1 $\beta$ are present in the synovial fluid of patients with TMD ${ }^{46}$.

\section{Interleukin-1 (IL-6)}

IL-6 is a pleiotropic cytokine produced by some types of cells, such as synovial cells, monocytes, macrophages, and fibroblasts ${ }^{47}$. It regu- 
lates immune reactions, inflammation, hematopoiesis, and carcinogenesis $^{48,49}$, and also mediates the induction of the differentiation process of the osteoclast progenitor and the osteoclastic activity ${ }^{50}$. When a tissue injury occurs, IL-6 plasma concentrations are detectable within 60 minutes, with a peak between 4 and 6 hours that can persist for up to 10 days. IL- 6 promotes the maturation and activation of neutrophils, maturation of macrophages and the differentiation/maintenance of cytotoxic T-lymphocytes and natural killers cell $s^{51}$. Moreover, IL- 6 is important for the transition of acute inflammation to chronic ${ }^{52}$. The literature points IL- 6 as one of the major pro-inflammatory cytokines that contribute to the pathogenesis of the TMJ inflammation and disorders ${ }^{48,53-56}$.

\section{CONCLUSION}

Understanding the inflammatory process, with the different mediators and mechanisms can contribute to better knowledge, making possible to select the best therapy to be used in the cases of temporomandibular arthralgias.

\section{REFERENCES}

1. Schiffman E, Ohrbach R, Truelove E, Look J, Anderson G, Goulet JP, et al. Diagnostic Criteria for Temporomandibular Disorders (DC/TMD) for Clinical and Research Applications: recommendations of the International RDC/TMD Consortium Network and Orofacial Pain Special Interest Group. J Oral Facial Pain Headache. 2014;28(1):6-27.

2. Okeson JP. Joint intracapsular disorders: diagnostic and nonsurgical management considerations. Dent Clin North Am. 2007;51(1):85-103.

3. Wadhwa S, Kapila S. TMJ disorders: future innovations in diagnostics and therapeutics. J Dent Educ. 2008;72(8):930-47.

4. Manfredini D, Guarda-Nardini L, Winocur E, Piccotti F, Ahlberg J, Lobbezoo F. Research diagnostic criteria for temporomandibular disorders: a systematic review of axis I epidemiologic findings. Oral Surg Oral Med Oral Pathol Oral Radiol Endod. 2011;112(4):453-62.

5. Carrara SV, Conti PC, Barbosa JS. Termo do $1^{\circ}$ Consenso em Disfunçâo Temporomandibular e Dor Orofacial. Dental Press J Orthod. 2010;15(3):114-20.

6. Young AL. Internal derangements of the temporomandibular joint: a review of the anatomy, diagnosis, and management. J Indian Prosthodont Soc. 2015;15(1):2-7.

7. Brunton LL, Chabner BA, Knollman BA. As Bases Farmacológicas da Terapêutica de Goodman e Gilman. 12a ed. McGraw Hill; 2012. 563-600p.

8. Consolaro A. Inflamação e Reparo. 2a ed. Dental Press; 2015. 63-120p.

9. Rahmati M, Mobasheri A, Mozafari M. Inflammatory mediators in osteoarthritis: a critical review of the state-of-the art, current prospects, and future challenges. Bone. 2016;81-90.

10. Bouloux GF. Temporomandibular joint pain and synovial fluid analysis: a review of the literature. J Oral Maxillofac Surg. 2009;67(11):2497-504.

11. Ernberg $M$. The role of molecular pain biomarkers in temporomandibular joint internal derangement. J Oral Rehabil. 2017;44(6):481-91.

12. Wieckiewicz M, Boening K, Wiland P, Shiau YY, Paradowska-Stolarz A. Reported concepts for the treatment modalities and pain management of temporomandibular disorders. J Headache Pain. 2015;16:106.

13. Hosgor H, Bas B, Celenk C. A comparison of the outcomes of four minimally invasive treatment methods for anterior disc displacement of the temporomandibular joint. Int J Oral Maxillofac Surg. 2017;46(11):1403-10.

14. Okeson JP. Tratamento das desordens temporomandibulares e oclusão. $7^{\mathrm{a}} \mathrm{ed}$. Mosby Elsevier; 2013. 154-5p.

15. Valle RT, Grossmann E, Fernandes RSM. Disfunçóes Temporomandibulares: Abordagem Clínica. $1^{\text {a }}$ ed. Napoleão; 2015. 80-102p.

16. Gynther GW, Dijkgraaf LC, Reinholt FP, Holmlund AB, Liem RS, de Bont LG. Synovial inflammation in arthroscopically obtained biopsy specimens from the temporomandibular joint: a review of the literature and a proposed histologic grading system. J Oral Maxillofac Surg. 1998;56(11):1281-6.

17. Israel HA. Internal derangement of the temporomandibular joint: new perspectives on an old problem. Oral Maxillofac Surg Clin North Am. 2016;28(3):313-33.

18. de Bont LG, Dijkgraaf LC, Stegenga B. Epidemiology and natural progression of articular temporomandibular disorders. Oral Surg Oral Med Oral Pathol Oral Radiol Endod. 1997;83(1):72-6.

19. Oliveira Junior JO, Portella Junior CS, Cohen CP. Inflammatory mediators of neuropathic pain. Rev Dor. 2016;17(Suppl 1):35-42.

20. Yagiela JA, Dowd FJ, Johnson B, Mariotti A. Farmacologia e Terapêutica para Dentistas. 6a ed. Mosby Elsevier; 2011. 318-52p.
21. Henry CH, Wolford LM. Substance P and mast cells: preliminary histologic analysis of the human temporomandibular joint. Oral Surg Oral Med Oral Pathol Oral Radiol Endod. 2001;92(4):384-9.

22. Li W, Long X, Jiang S, Li Y, Fang W. Histamine and substance P in synovial fluid of patients with temporomandibular disorders. J Oral Rehabil. 2015;42(5):363-9.

23. Ting E, Roveroni RC, Ferrari LF, Lotufo CM, Veiga MC, Parada CA, et al. Indirect mechanism of histamine-induced nociception in temporomandibular joint of rats. Life Sci. 2007;81(9):765-71.

24. Wannamacher L, Ferreira MBC. Farmacologia Clínica para Dentistas. $3^{\mathrm{a}}$ ed. Guanabara Koogan; 2007. 129-43p.

25. Alstergren P, Kopp S. Pain and synovial fluid concentration of serotonin in arthritic temporomandibular joints. Pain. 1997;72(2):137-43.

26. Oliveira-Fusaro MC, Clemente-Napimoga JT, Teixeira JM, Torres-Chávez KE, Parada CA, Tambeli CH. 5-HT induces temporomandibular joint nociception in rats through the local release of inflammatory mediators and activation of local $\beta$ adrenoceptors. Pharmacol Biochem Behav. 2012;102(3):458-64.

27. Suzuki T, Segami N, Nishimura M, Sato J, Nojima T. Bradykinin expression in synovial tissues and synovial fluids obtained from patients with internal derangement of the temporomandibular joint. Cranio. 2003;21(4):265-70.

28. Kaneyama K, Segami N, Sato J, Fujimura K, Nagao T, Yoshimura H. Prognostic factors in arthrocentesis of the temporomandibular joint: comparison of bradykinin, leukotriene B4, prostaglandin E2, and substance P level in synovial fluid between successful and unsuccessful cases. J Oral Maxillofac Surg. 2007;65(2):242-7.

29. Nishimura M, Segami N, Kaneyama K, Suzuki T, Miyamaru M. Relationships between pain-related mediators and both synovitis and joint pain in patients with internal derangements and osteoarthritis of the temporomandibular joint. Oral Surg Oral Med Oral Pathol Oral Radiol Endod. 2002;94(3):328-32.

30. Alstergren P, Kopp S. Prostaglandin E2 in temporomandibular joint synovial fluid and its relation to pain and inflammatory disorders. J Oral Maxillofac Surg. 2000;58(2):180-6.

31. Zhang P, Gan YH. Prostaglandin E2 upregulated trigeminal ganglionic sodium channel 1.7 involving temporomandibular joint inflammatory pain in rats. Inflammation. 2017;40(3):1102-9.

32. Quinn JH, Bazan NG. Identification of prostaglandin E2 and leukotriene B4 in the synovial fluid of painful, dysfunctional temporomandibular joints. J Oral Maxillofac Surg. 1990;48(9):968-71.

33. Schütz TC, Andersen ML, Tufik S. Influence of temporomandibular joint pain on sleep patterns: role of nitric oxide. J Dent Res. 2004 ;83(9):693-7.

34. Güven O, Tozoğlu S, Tekin U, Salmanoğlu B, Güneș O. Relationship between activity of gluthatione peroxidase and nitric oxide in synovial fluid and the progression of temporomandibular joint internal derangement. J Craniofac Surg. 2015;26(3):e210-3.

35. de Oliveira CM, Sakata RK, Issy AM, Gerola LR, Salomão R. [Cytokines and pain]. Rev Bras Anestesiol. 2011;61(2):255-65. English, Portuguese, Spanish.

36. Kaneyama K, Segami N, Sun W, Sato J, Fujimura K. Levels of soluble cytokine factors in temporomandibular joint effusions seen on magnetic resonance images. Oral Surg Oral Med Oral Pathol Oral Radiol Endod 2005;99(4):411-8.

37. Kellesarian SV, Al-Kheraif AA, Vohra F, Ghanem A, Malmstrom H, Romanos GE, et al. Cytokine profile in the synovial fluid of patients with temporomandibular joint disorders: a systematic review. Cytokine. 2016;77:98-106.

38. Curfs JH, Meis JF, Hoogkamp-Korstanje JA. A primer on cytokines: sources, receptors, effects, and inducers. Clin Microbiol Rev. 1997;10(4):742-80.

39. Raeburn CD, Sheppard F, Barsness KA, Arya J, Harken AH. Cytokines for surgeons. Am J Surg. 2002;183(3):268-73.

40. Furquim BD, Flamengui LM, Repeke CE, Cavalla F, Garlet GP, Conti PC. Influence of TNF- $\alpha-308$ G/A gene polymorphism on temporomandibular disorder. Am J Orthod Dentofacial Orthop. 2016;149(5):692-8.

41. Taylor PC, Williams RO, Feldmann M. Tumour necrosis factor alpha as a therapeutic target for immune-mediated inflammatory diseases. Curr Opin Biotechnol. 2004;15(6):557-63.

42. Fredriksson L, Alstergren P, Kopp S. Tumor necrosis factor-alpha in temporomandibular joint synovial fluid predicts treatment effects on pain by intra-articular glucocorticoid treatment. Mediators Inflamm. 2006;2006(6):59425.

43. Ahmed N, Petersson A, Catrina AI, Mustafa H, Alstergren P. Tumor necrosis factor mediates temporomandibular joint bone tissue resorption in rheumatoid arthritis. Acta Odontol Scand. 2015;73(3):232-40.

44. Contassot E, Beer HD, French LE. Interleukin-1, inflammasomes, autoinflammation and the skin. Swiss Med Wkly. 2012;142:w13590.

45. Tominaga K, Habu M, Sukedai M, Hirota Y, Takahashi T, Fukuda J. IL-1 beta, IL-1 receptor antagonist and soluble type II IL-1 receptor in synovial fluid of patients with temporomandibular disorders. Arch Oral Biol. 2004;49(6):493-9.

46. Sorenson A, Hresko K, Butcher S, Pierce S, Tramontina V, Leonardi R, et al. Expression of Interleukin-1 and temporomandibular disorder: contemporary review of the literature. Cranio. 2017;19:1-5. [Epub ahead of print].

47. Nishimoto N, Kishimoto T, Yoshizaki K. Anti-interleukin 6 receptor antibody treatment in rheumatic disease. Ann Rheum Dis. 2000;59 (Suppl 1):i21-7.

48. Gunson MJ, Arnett GW, Milam SB. Pathophysiology and pharmacologic control of osseous mandibular condylar resorption. J Oral Maxillofac Surg. 2012;70(8):1918-34.

49. Sato J, Segami N, Nishimura M, Demura N, Yoshimura H, Yoshitake Y, et al. Expression of interleukin 6 in synovial tissues in patients with internal derangement of the temporomandibular joint. Br J Oral Maxillofac Surg. 2003;41(2):95-101. 
50. Fu K, Ma X, Zhang Z, Pang X, Chen W. Interleukin-6 in synovial fluid and HLADR expression in synovium from patients with temporomandibular disorders. J Orofac Pain. 1995;9(2):131-7.

51. Lin E, Calvano SE, Lowry SF. Inflammatory cytokines and cell response in surgery. Surgery, 2000;127(2):117-26.

52. Kaplanski G, Marin V, Montero-Julian F, Mantovani A, Farnarier C. IL-6: a regulator of the transition from neutrophil to monocyte recruitment during inflammation. Trends Immunol. 2003;24(1): 25-9.

53. Yamamoto M, Yoshizaki K, Kishimoto T, Ito H. IL-6 is required for the development of Th-1 cell-mediated murine colitis. J Immunol. 2000;164(9):4878-82.

54. Alonzi T, Fattori E, Lazzaro D, Costa P, Probert L, Kollias G, et al. Interleukin-6 is required for the development of collagen induced arthritis. J Exp Med. 1998;187(4):461-8.

55. Gunson MJ, Arnett GW, Milam SB. Pathophysiology and pharmacologic control of osseous mandibular condylar resorption. J Oral Maxillofac Surg. 2012;70(8):1918-34.

56. De Alcântara Camejo F, Azevedo M, Ambros V, Caporal KST, Doetzer AD, Almeida LE, et al. Interleukin- 6 expression in disc derangement of human temporomandibular joint and association with osteoarthrosis. J Craniomaxillofac Surg. 2017;45(5):768-74. 